\title{
PENGARUH MODEL PEMBELAJARAN PROBLEM BASED LEARNING TERHADAP MOTIVASI DAN HASIL BELAJAR PEMELIHARAAN BATERAI PADA SISWA KELAS X TKR SMK NEGERI 1 CANGKRINGAN TAHUN PELAJARAN 2018/2019
}

\author{
Brian Pradana Putra \\ SMK Negeri 1 Cangkringan Yogyakarta \\ Email: brianpradana08@yahoo.com
}

\begin{abstract}
This quasi-experimental research in education aims to determine the effect of Problem Based Learning models on motivation and learning outcomes of Battery Maintenance in class X TKR, SMK Negeri 1 Cangkringan in the academic year 2018/2019. The data were taken using a questionnaire and tests. The subjects of this study were 64 students consisting of 32 control class students and 32 experimental class students. Hypothesis testing in this study uses t-test between groups. T-test between groups was used to determine differences in learning motivation of the experimental class and control class after being treated, to find out the difference of learning outcomes in experimental class and control class after being given treatment. The results showed that the learning motivation of the experimental class with Problem Based Learning model was higher than the control class with the lecture method and the learning outcomes of the experimental class with the Problem Based Learning model were not higher than the control class with the lecture method on the Battery Maintenance material in class X TKR SMK Negeri 1 Cangkringan, academic year 2018/2019.
\end{abstract}

Keywords: experimental methods, problem based learning, learning motivation, learning outcomes, battery maintenance.

\begin{abstract}
Abstrak
Penelitian eksperimen kuasi dalam pendidikan ini bertujuan untuk mengetahui pengaruh model pembelajaran Problem Based Learning terhadap motivasi dan hasil belajar Pemeliharaan Baterai pada siswa kelas X TKR SMK Negeri 1 Cangkringan tahun pelajaran 2018/2019. Data dalam penelitian ini diambil dengan menggunakan angket dan tes. Subjek penelitian ini ialah 64 siswa terdiri dari 32 siswa kelas kontrol dan 32 siswa kelas eksperimen. Pengujian hipotesis dalam penelitian ini menggunakan uji$\mathrm{t}$ antar kelompok. Uji-t antar kelompok digunakan untuk mengetahui perbedaan motivasi belajar siswa kelas eksperimen dan kelas kontrol setelah diberi perlakuan, untuk mengetahui perbedaan hasil belajar kelas eksperimen dan kelas kontrol setelah diberi perlakuan. Hasil penelitian menunjukan bahwa motivasi belajar kelas eksperimen dengan model Problem Based Learning lebih tinggi dibandikan dengan kelas kontrol dengan metode ceramah dan hasil belajar kelas eksperimen dengan model Problem Based Learning tidak lebih tinggi dibandingkan dengan kelas kontrol dengan metode ceramah pada materi Pemeliharaan Baterai pada siswa kelas X TKR SMK Negeri 1 Cangkringan tahun pelajaran 2018/2019.
\end{abstract}

Kata kunci: metode eksperimen, problem based learning, motivasi belajar, hasil belajar, pemeliharaan baterai

\section{PENDAHULUAN}

Pendidikan kejuruan adalah pendidikan yang diselenggarakan bagi para siswa yang merencanakan dan mengembangkan karirnya pada bidang keahlian tertentu untuk bekerja secara produktif. Pendidikan kejuruan dirancang untuk mengembangkan keterampilan, 


\section{Brian Pradana Putra}

kemampuan, pemahaman, sikap, kebiasaan-kebiasaan kerja, dan apresiasi yang diperlukan oleh pekerja dalam memasuki pekerjaan dan membuat kemajuan-kemajuan dalam pekerjaan penuh makna dan produktif (Adhikary, 2005).

Berdasarkan pengamatan yang dilakukan di lapangan, peneliti mengidentifikasi masalahmasalah yang terjadi di SMK Negeri 1 Cangkringan sebagai berikut:

1. Guru masih menggunakan metode ceramah dalam pembelajaran sehingga siswa menjadi pasif dan bosan dalam menerima pelajaran

2. Motivasi belajar siswa pada saat mengikuti pembelajaran dengan menggunakan metode ceramah menjadi rendah.

3. Rata-rata nilai hasil belajar siswa setelah mengikuti pembelajaran dengan menggunakan metode ceramah menjadi berada di bawah Kriteria Ketuntasan Minimal (KKM).

4. Fasilitas tempat praktik dan peralatan praktek masih kurang memadahi jika melihat standar yang ditetapkan peraturan menteri pendidikan nasional Republik Indonesia nomor 40 tahun 2008 tentang sarana prasarana untuk Sekolah Menengah Kejuruan/Madrasah Aliyah Kejuruan.

Oeh karena itu, penelitian ini bertujuan untuk 1) mengetahui perbedaan motivasi belajar siswa yang diajarkan dengan model pembelajaran Problem Based Learning dibandingkan siswa yang diajarkan dengan metode ceramah pada materi Pemeliharaan Baterai pada siswa kelas $\mathrm{X}$ TKR SMK Negeri 1 Cangkringan tahun pelajaran 2018/2019; 2) mengetahui perbedaan hasil belajar siswa yang diajarkan dengan model pembelajaran Problem Based Learning dibandingkan siswa yang diajarkan dengan metode ceramah pada materi Pemeliharaan Baterai pada siswa kelas X TKR SMK Negeri 1 Cangkringan tahun pelajaran 2018/2019. Hasil yang didapatkan dari penelitian ini diharapkan dapat meningkatkan motivasi dan hasil belajar siswa. Selain itu, guru juga dapat memperkaya model-model pembelajaran pada bidang PTK yang dapat meningkatkan motivasi dan hasil belajar siswa. Sedangkan bagi pengembang ilmu pendidikan, hasil penelitian ini dapat memberikan informasi baru model-model pembelajaran inovatif bidang kejuruan dan menjadi inspirasi untuk melakukan penelitian lebih lanjut.

\section{METODE}

Penelitian yang digunakan pada penelitian ini yaitu penelitian quasi experimental design. Sugiyono (2010:107) mendefinisikan bahwa penelitian eksperimen yaitu penelitian yang digunakan untuk mencari pengaruh perlakuan tertentu terhadap yang lain dalam kondisi yang terkendali. Penelitian ini dilaksanakan di SMK Negeri 1 Cangkringan yang terletak di Desa Sintokan, Wukirsari, Cangkringan. SMK Negeri 1 Cangkringan merupakan salah satu sekolah 
SMK di Kecamatan Cangkringan, dengan Visi sekolah yaitu Terwujudnya tamatan yang berbudi pekerti luhur, terampil, tangguh, handal, dan mandiri yang dilandasi iman dan taqwa.

Subyek penelitian ini adalah siswa kelas X TKR semester genap SMK Negeri 1 Cangkringan tahun ajaran 2018/2019 yang berjumlah 64 siswa yang terbagi dalam 2 kelas, terdiri dari kelas X TKR 1 dan kelas X TKR 2 dengan jumlah masing-masing kelas yaitu 32 siswa. Subyek penelitian ini adalah kelas X TKR 2 sebagai kelas eksperimen dan kelas X TKR 1 sebagai kelas kontrol. Pembelajaran dilakukan pada materi Pemeliharaan Baterai.

Untuk instrumen motivasi belajar, menggunakan angket motivasi belajar. Angket ini modifikasi dari instrumen Bernaditya Listiono yang terdiri dari 30 butir pertanyaan dengan koefisien reliabilitas sebesar 0,731. Adopsi angket yang digunakan dilakukan karena kesamaan dalam mengungkap hal yaitu motivasi belajar siswa. Metode tes dipilih untuk mengukur pencapaian kompetensi dasar dan kompetensi inti pada kategori pengetahuan dan keterampilan, dalam hal ini untuk mengukur hasil belajar siswa. Tes yang dilakukan dalam penelitian ini adalah tes tulis dengan bentuk soal pilihan ganda. Tes tertulis merupakan tes dimana soal dan jawaban yang diberikan kepada peserta didik dalam bentuk tulisan. Dalam menjawab soal peserta didik tidak selalu merespon dalam bentuk menulis jawaban tetapi juga dalam bentuk lain seperti memberi tanda, mewarnai, menggambar dan sebagainya.

Sebelum dilakukan analisis data, terlebih dahulu dilakukan uji persyaratan hipotesis. Uji persyaratan hipotesis terdiri atas uji normalitas dan uji homogenitas. Uji normalitas bertujuan untuk mengetahui apakah data dari masing-masing variabel berdistribusi normal atau tidak. Uji normalitas dilakukan terhadap data pengetahuan awal dengan data hasil belajar siswa, data hasil belajar siswa, data pengukuran motivasi belajar siswa awal dan akhir. Uji yang dipakai dalam penelitian ini adalah uji chi kuadrat dengan langkah-langkah sebagai berikut (Sugiyono, 2013:78-79):

1) Menyusun data dari yang tertinggi ke arah yang terendah.

2) Membuat interval kelas dan menentukan batas kelasnya.

3) Menghitung harga $z$ dengan rumus : $z=\frac{x-\bar{x}}{s}$

Dengan $\mathrm{X}=$ Data ke-i dari suatu kelompok data

$$
\begin{aligned}
& \overline{\mathrm{X}}=\text { Rata-rata kelompok } \\
& \mathrm{s}=\text { simpangan baku }
\end{aligned}
$$

4) Harga $z$ diubah menjadi luasan daerah kurva normal dengan menggunakan tabel kurva normal.

5) Menghitung frekuensi harapan berdasarkan luasan kurva normal. 


\section{Brian Pradana Putra}

6) Menghitung $\chi^{2}$ dengan rumus $=x^{2}=\sum_{\mathrm{i}=\mathrm{i}}^{\mathrm{k}} \frac{\left(\mathrm{f}_{0}-\mathrm{f}_{\mathrm{h}}\right)^{2}}{\mathrm{f}_{\mathrm{h}}}$

Menjumlahkan harga-harga $\chi^{2}$ pada langkah $\mathrm{f}$ ), kemudian membandingkan dengan harga $\chi^{2}$ tabel pada taraf signifikan $5 \%$ dan $\mathrm{db}=\mathrm{k}-1$. Data berdistribusi normal jika harga $\chi^{2}$ hitung $>$

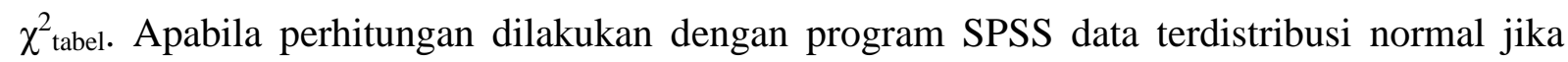
diperoleh $\mathrm{p}>0,05$.

Uji homogenitas bertujuan untuk mengetahui sampel berasal dari populasi yang homogen atau tidak. Uji homogenitas ini dilakukan terhadap pengetahuan awal dengan data prestasi belajar peserta didik. Uji homogenitas yang digunakan mengunakan uji F-max(Agus Irianto, 2004:276) yaitu :

1) Menghitung variansi masing-masing kelompok $\left(\mathrm{SB}^{2}\right)$

2) Menghitung harga $F$ dengan rumus:

$$
\mathrm{F}=\frac{\mathrm{SB}_{\mathrm{b}}{ }^{2}}{\mathrm{SB}_{\mathrm{k}}{ }^{2}} \text { atau } \mathrm{F}=\frac{\text { variabel terbesar }}{\text { variabel terkecil }}
$$

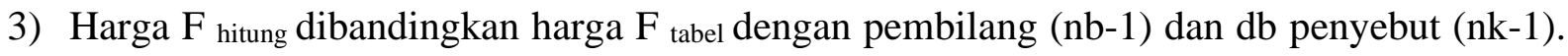

Data berasal dari populasi yang homogen jika $F_{\text {hitung }} \leq \mathrm{F}_{\text {tabel, }}$, atau analisis dengan program komputer. Apabila perhitungan dilakukan dengan program SPSS data terdistribusi normal jika diperoleh $\mathrm{p}>0,05$.

Untuk menguji hipotesis digunakan analisis uji t antar kelompok. Analisis ini digunakan untuk mengetahui ada tidaknya pebedaan keadaan satu faktor dengan dua sampel. Yang dimaksud satu faktor adalah hanya ada satu faktor yang terdapat dalam subjek penelitian yang diamati, faktor pertama yang diamati yaitu motivasi belajar dan faktor kedua yang diamati yaitu hasil belajar, sedangkan dua sampel berarti hanya ada dua kelas yang dibandingkan yaitu kelas eksperimen dan kelas kontrol. Hipotesis alternatif tersebut diuji menggunakan uji $\mathrm{t}$ antar kelompok (Sugihartono,2013:134) dengan rumus sebagai berikut:

$$
\mathrm{t}=\frac{\bar{X}_{1}-\bar{X}_{2}}{\sqrt{\frac{\mathrm{s}_{1}^{2}}{\mathrm{n}_{1}}+\frac{\mathrm{s}_{2}^{2}}{\mathrm{n}_{2}}}}
$$

Keterangan:

$\overline{\mathrm{X}}_{1}=$ rata - rata sampel 1

$\overline{\mathrm{X}}_{2}=$ rata - rata sampel 2

$\mathrm{s}=$ simpangan baku

$\mathrm{s}_{1}=$ simpangan baku untuk data kelompok 1

$\mathrm{s}_{2}=$ simpangan baku untuk data kelompok 2

$\mathrm{n}_{1}=$ jumlah anggota kelompok 1 
$\mathrm{n}_{2}=$ jumlah anggota kelompok 2

* penguji hipotesis :

$$
\mathrm{H}_{\mathrm{o}}: \mu_{1}=\mu_{2} \quad \mathrm{H}_{\mathrm{a}}: \mu_{1} \neq \mu_{2}
$$

Dengan :

$\mu_{1}=$ rata-rata skor prestasi belajar kelas eksperimen

$\mu_{2}=$ rata-rata skor prestasi kelas kontrol

Harga $t_{0}$ dibandingkan dengan $t_{\text {tabel }}$ pada taraf signifikansi 5\%. Ho diterima, jika $p>0,05$ dan Ho ditolak jika $\mathrm{p}<0,05$. Sedangkan Ha diterima, jika $\mathrm{p}<0,05$ dan Ha ditolak jika $\mathrm{p}>0,05$. Uji t sama subjek dilakukan dengan menggunakan program komputer.

\section{HASIL DAN PEMBAHASAN}

Data yang digunakan dalam penelitian ini terdiri dari empat macam yaitu data pengetahuan awal siswa, data motivasi awal siswa, data hasil belajar siswa setelah diberi perlakuan dan data motivasi belajar siswa setelah diberi perlakuan. Data pengetahuan awal yang digunakan merupakan nilai ulangan materi pemeliharaan baterai yang telah dilakukan oleh guru pengampu mata pelajaran pemeliharaan baterai dimana pembelajaran dilakukan dengan metode ceramah.

Tabel 8. Distribusi Data Hasil Belajar Kelas Eksperimen

\begin{tabular}{ccccc}
\hline & \multicolumn{4}{c}{ Kelas Eksperimen } \\
Interval Nilai & \multicolumn{2}{c}{ X } & \multicolumn{2}{c}{$Y$} \\
& Jumlah & $\sum_{0}$ & Jumlah & $\sum_{0}$ \\
\hline$>70$ & 4 & 289,00 & 18 & 1400,88 \\
$66-70$ & 6 & 407,00 & 0 & 0 \\
$61-65$ & 8 & 513,00 & 7 & 452,90 \\
$56-60$ & 8 & 471,00 & 4 & 235,28 \\
$51-55$ & 4 & 215,00 & 1 & 52,94 \\
$46-50$ & 0 & 0 & 0 & 0 \\
Jumlah Siswa & \multicolumn{2}{c}{30} & \multicolumn{2}{c}{30} \\
Nilai Tertinggi & \multicolumn{2}{c}{73,00} & \multicolumn{2}{c}{88,23} \\
Nilai Terendah & \multicolumn{2}{c}{53,00} & \multicolumn{2}{c}{52,94} \\
Rata-rata Kelas & 63,17 & \multicolumn{2}{c}{71,40} \\
\hline
\end{tabular}

Tabel 9. Distribusi Data Hasil Belajar Kelas Kontrol

\begin{tabular}{ccccc}
\hline \multirow{2}{*}{ Interval Nilai } & \multicolumn{4}{c}{ Kelas Kontrol } \\
& Jumlah & $\sum_{0}$ & Jumlah & $\sum_{0}$ \\
\hline$>70$ & 0 & 0 & 13 & 976,47 \\
$66-70$ & 5 & 341,00 & 0 & 0 \\
$61-65$ & 12 & 759,00 & 8 & 517,60 \\
$56-60$ & 9 & 526,00 & 7 & 411,74
\end{tabular}




\begin{tabular}{ccccc} 
51-55 & 4 & 217,00 & 3 & 158,82 \\
$46-50$ & 2 & 99,0 & 1 & 47,05 \\
Jumlah Siswa & 32 & \multicolumn{2}{c}{32} \\
Nilai Tertinggi & 70,00 & 88,23 \\
Nilai Terendah & 49,00 & 47,05 \\
Rata-rata Kelas & 60,68 & 68,06 \\
\hline
\end{tabular}

Data motivasi belajar siswa diperoleh berdasarkan angket motivasi belajar yang diberikan sebelum dan sesudah kedua kelas sampel diberikan perlakuan.

\begin{tabular}{ccccc} 
Tabel 10. Distribusi Data Motivasi Belajar Kelas Eksperimen \\
\hline \multicolumn{5}{c}{ Kelas Eksperimen } \\
Interval Nilai & X & \multicolumn{3}{c}{ Y } \\
& Jumlah & $\sum_{0}$ & Jumlah & $\sum_{0}$ \\
\hline$>100$ & 9 & 944,00 & 28 & 3018,00 \\
$96-100$ & 9 & 873,00 & 2 & 199,00 \\
$91-95$ & 5 & 457,00 & 0 & 0 \\
$86-90$ & 4 & 357,00 & 0 & 0 \\
$81-85$ & 3 & 252,00 & 0 & 0 \\
$76-80$ & 0 & 0 & 0 & 0 \\
Jumlah Siswa & \multicolumn{3}{c}{30} & \multicolumn{2}{c}{30} \\
Nilai Tertinggi & \multicolumn{2}{c}{109} & \multicolumn{2}{c}{117} \\
Nilai Terendah & 83 & \multicolumn{2}{c}{99} \\
Rata-rata Kelas & 96,10 & \multicolumn{4}{c}{107,23} \\
\hline
\end{tabular}

Tabel 11. Distribusi Data Motivasi Belajar Kelas Kontrol

\begin{tabular}{ccccc}
\hline & \multicolumn{4}{c}{ Kelas Kontrol } \\
Interval Nilai & \multicolumn{2}{c}{ X } & \multicolumn{2}{c}{$\mathrm{Y}$} \\
& Jumlah & $\sum_{0}$ & Jumlah & $\sum_{0}$ \\
\hline$>100$ & 12 & 1459,00 & 25 & 2679,00 \\
$96-100$ & 7 & 482,00 & 3 & 297,00 \\
$91-95$ & 8 & 740,00 & 2 & 188,00 \\
$86-90$ & 5 & 445,00 & 2 & 180,00 \\
$81-85$ & 0 & 0 & 0 & 0 \\
$76-80$ & 0 & 0 & 0 & 0 \\
Jumlah Siswa & \multicolumn{2}{c}{32} & \multicolumn{2}{c}{32} \\
Nilai Tertinggi & \multicolumn{2}{c}{110} & \multicolumn{2}{c}{114} \\
Nilai Terendah & \multicolumn{2}{c}{87} & \multicolumn{2}{c}{90} \\
Rata-rata Kelas & \multicolumn{2}{c}{97,69} & 104,5 \\
\hline
\end{tabular}

Data penelitian menunjukan bahwa metode pembelajaran problem based learning dapat meningkatkan motivasi dan hasil belajar peserta didik (Tafakur \& Suyanto, 2015). Hal ini sesuai dengan hasil penelitian Nurtanto dan Sofyan (2015) yang menyatakan bahwa penerapan problem based learning dapat meningkatkan kemampuan kognitif dan psikomotorik siswa. 


\section{SIMPULAN}

Berdasarkan hasil dari penelitian ini, dapat disimpulkan bahwa terdapat perbedaan motivasi belajar antara siswa yang diajarkan dengan model pembelajaran Problem Based Learning dengan siswa yang diajarkan dengan metode ceramah pada materi Pemeliharaan Baterai pada siswa kelas X TKR SMK Negeri 1 Cangkringan tahun pelajaran 2018/2019. Akan tetapi, tidak ada perbedaan hasil belajar antara siswa yang diajarkan dengan model pembelajaran Problem Based Learning dengan siswa yang diajarkan dengan metode ceramah pada materi Pemeliharaan Baterai pada siswa kelas X TKR SMK Negeri 1 Cangkringan tahun pelajaran 2018/2019.

Oleh karena itu, disarankan supaya pendidik dapat menggunakan model pembelajaran Problem Based Learning dalam menyampaikan materi Pemeliharaan Baterai serta materi lain untuk meningkatkan motivasi siswa dalam pembelajaran. Selain itu, lembaga pendidikan dapat meningkatkan mutu pendidikan dengan menyediakan fasilitas yang mendukung model pembelajaran Problem Based Learning sehingga dapat memfasilitasi peningkatan motivasi belajar siswa.

\section{DAFTAR PUSTAKA}

Adhikary, P.K. 2005. Educational Reform For Linking Skills Development With Employment In Nepal. In M SINGH (Eds), Meeting Basic Learning Needs in the Informal Sector Integrating Education and Training for Decent Work, Empowerement and Citizenship. Hamburg, Germany: UNESCO Institute foe Eduacation.

Agus Irianto. 2004. Statistika Konsep Dasar dan Aplikasinya. Jakarta: Prenada Media.

Nurtanto, M., \& Sofyan, H. (2015). Implementasi problem-based learning untuk meningkatkan hasil belajar kognitif, psikomotor, dan afektif siswa di SMK. Jurnal Pendidikan Vokasi, 5(3), 352-364.

Sugihartono dkk. 2013. Psikologi Pendidikan. Yogyakarta: UNY Press.

Sugiyono. 2010. Metode Penelitian Pendidikan Pendekatan Kuantitatif, Kualitatif dan R\&D. Bandung: Alfabeta.

Sugiyono. 2013. Statistika untuk Penelitian. Bandung: Alfabeta.

Tafakur, T., \& Suyanto, W. (2015). Pengaruh cooperative project-based learning terhadap motivasi dan hasil belajar praktik "perbaikan motor otomotif" di SMKN 1 Seyegan. Jurnal Pendidikan Vokasi, 5(1), 117-131. 